\title{
Protein creatinine index and Albustix in assessment of proteinuria
}

\author{
ALLEN B SHAW, PAUL RISDON, JUDITH D LEWIS-JACKSON
}

\begin{abstract}
The protein creatinine index in early morning and random urine specimens was compared with the 24 hour urinary excretion of protein in normal subjects and outpatients with abnormal proteinuria. A protein creatinine index (defined as ( $\mathrm{mg}$ protein/1 divided by creatinine mmol/1) times 10) below 125 in a random specimen excluded abnormal proteinuria, whereas an index of more than 136 indicated the presence of pathological proteinuria. The index for random specimens provided a useful semiquantitative assessment of the 24 hour excretion of protein ( $\mathrm{mg}$ protein/24 hours), but the index for early morning specimens was less reliable. Errors with Albustix were partly due to intra and inter observer variations in the interpretation of the colour formed when compared with the chart provided.

It is proposed that the protein creatinine index on random urine samples should be used to supplement dipsticks in screening for proteinuria in cases where misclassification would be serious.
\end{abstract}

\section{Introduction}

Minor degrees of proteinuria may indicate the presence of important renal disease. ${ }^{1}$ Measurement of the protein content of a timed 24 hour urine collection is the definitive method of establishing the presence of abnormal proteinuria. ${ }^{2}$ Timed collections of urine are inconvenient, expensive, and unreliableup to a third of collections have to be rejected. ${ }^{3}$ We compared

Bradford Royal Infirmary, Bradford BD9 6RJ

ALLEN B SHAW, MD, FRCP, consultant physician

PAUL RISDON, MSC, senior chief medical laboratory scientific officer, biochemistry department

JUDITH D LEWIS-JACKSON, FIMLS, medical laboratory scientific officer, biochemistry department

Correspondence to: Dr Allen B Shaw. protein creatinine index in random and early morning urine samples with 24 hour excretion of protein in normal subjects and in outpatients with varying degrees of proteinuria. The aims were to determine if the index would be a useful screening test for proteinuria, and also if it would provide a semiquantitative measurement of the 24 hour excretion of protein.

Dipstick tests are widely used to screen for proteinuria but their unreliability has been frequently documented. ${ }^{4-6}$ During the study the sensitivity and specificity of Albustix were assessed on the same specimens used for the protein creatinine index. Intra and inter observer variations in the interpretation of Albustix results were evaluated when using urine samples of known protein concentration.

\section{Patients and methods}

A total of 10 laboratory staff (group 1) and 81 outpatients were studied. The outpatients were allocated into four groups according to their daily excretion of protein. Group 2 comprised 32 patients who had no renal disease and excreted less than $150 \mathrm{mg}$ protein/day. Group 3 contained 27 patients with renal disease of various types who excreted 150 to $1000 \mathrm{mg}$ protein/day. Group 4 comprised 14 patients with serious renal disease whose daily excretion of protein was 1000 $3500 \mathrm{mg}$. Group 5 comprised eight patients excreting more than $3500 \mathrm{mg}$ protein/day (in the nephrotic range). No patients were in advanced renal failure.

Careful oral and written instructions about the collections were given and the urine samples were collected as follows: on day 1 the early morning specimen was collected, the time noted, and all urine for the next 24 hours was collected. A random specimen was collected separately. The patient was questioned on the completeness of the 24 hour collection, which was rejected if errors were admitted. Collections were also rejected as probably incomplete if total daily excretion of creatinine was less than $20 \mathrm{mg} / \mathrm{kg}$ body weight in men or less than $15 \mathrm{mg} / \mathrm{kg}$ body weight in women. ${ }^{7}$ This further check was not used for patients previously classified as considerably obese or wasted. $^{8}$

Each urine sample was analysed for protein, creatinine, albumin, and $\mathrm{pH}$. Albustix were used according to the manufacturer's instructions, and $\mathrm{pH}$ was measured using narrow range indicator strips. Urinary total protein was based on a turbidimetric method using a quarternary ammonium salt, ${ }^{9}$ and creatinine was measured by alkaline picrate on a sequential multiple analyser computerised autoanalyser. ${ }^{10}$ 
The protein creatinine index was calculated as $(\mathrm{mg}$ protein/1 mmol creatinine/1) $\times 10$. An index below 125 in a random specimen excluded proteinuria and an index above 136 indicated pathological proteinuria.

In a separate study four solutions of differing protein content (A, B, C, D) were prepared by making dilutions of a urine sample of high protein concentration and these were subdivided into four sets of duplicate samples. The protein concentrations were measured quantitatively as above. These eight samples were tested with Albustix by 15 people with normal colour vision (five laboratory staff, three doctors, three office staff, and four nurses). No one knew the concentration of protein to expect or that there were any duplicate samples. Specimens from group 1 (normal subjects) were not used for the Albustix study.

\section{Results}

By the criteria described above, $15 \%$ of collections were excluded from the study.

Group 1 (10 normal subjects)-The mean (SD) 24 hour excretion of protein was $77(30) \mathrm{mg}$. The mean protein creatinine index for random specimens was $62(29)$ and for early morning specimens was 50 (29).

Group 2 (patients with daily excretion of less than $150 \mathrm{mg}$ )-The mean 24 hour protein excretion was $83 \mathrm{mg} \mathrm{(28)}$. The mean index for random samples was $71(28)$ and the mean index for early morning samples was 57 (24).

The upper level of normal for both groups (mean, 2 SD) was 125 in the random specimens and 108 in the early morning specimens. This corresponds to the mean 24 hour protein excretion of $82 \mathrm{mg}$, with a 2 SD upper limit of $140 \mathrm{mg} /$ day. In both groups the highest index in random specimens was 136 and in early morning specimens 130.

\section{ALI PATIENTS WITH RENAL DISEASE (FIG 1)}

In group 3 (daily excretion of protein in the range 150-1000 mg) the mean 24 hour excretion of protein was $437 \mathrm{mg}$. The mean (SD) index for random specimens was $522(418)$ and the mean index for early morning specimens was 318 (231).

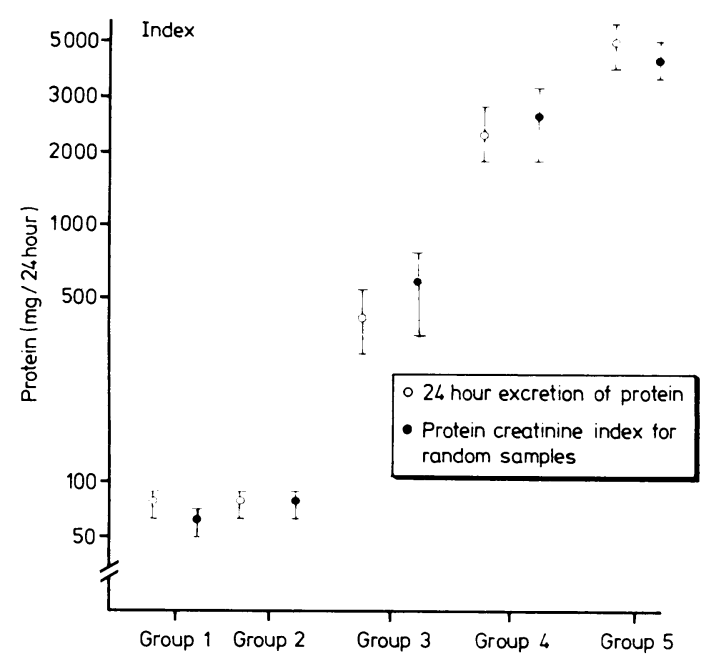

FIG 1-Mean (2 SEM) of 24 hour excretion of protein and protein creatinine index on random specimens of urine in five groups studied.

Group 4 (daily excretion of protein in the range 1000-3500 mg)The mean 24 hour excretion of protein was $2186 \mathrm{mg}$. The mean (SD) index for random samples was 2427 (1338) and the mean index for early morning samples was 1368 (632).

In group 5 (daily excretion of more than $3500 \mathrm{mg}$ protein/day) the mean 24 hour protein excretion was $4666 \mathrm{mg}$. The mean (SD) index for random samples was 4102 (567) and the mean index for early morning samples was 3018 (1322).
All patients excreting more than $150 \mathrm{mg}$ protein/day had an index for random specimens of more than 127. Four of the 27 patients in group 3, however, had an index for early morning specimens of less than 108-that is, false negatives. Twenty one of the patients in group 3 had an index of 127-1000 for random specimens and 22 had an index of 108-1000 for early morning specimens. Eleven of the 14 patients in group 4 had an index for random specimens in the range 1000-3500 and nine had an index for early morning specimens in the same range. Seven of the eight patients in group 5 had an index of more than 3500 for random specimens and three had an index for early morning specimens in the same range.

Thus in $78 \%$ of all cases the index for random specimens correlated numerically with 24 hour excretion. Indexes for random and early morning specimens showed a correlation of 0.94 with urinary excretion of protein $(\mathrm{mg} / 24$ hour). The regression equation relating 24 hour excretion (y) to the protein creatinine index (b) was $y=0.967 \mathrm{~b}+25$ (fig 2) for random specimens and $y=1.366 b+111$ for early morning specimens.

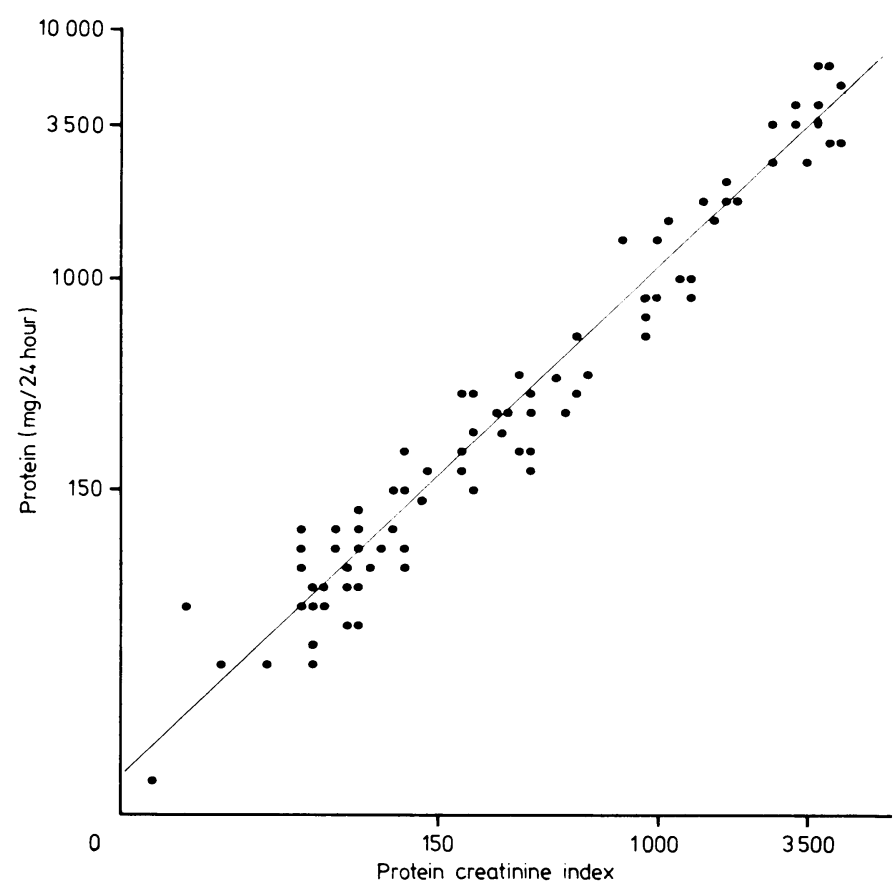

FIG 2-Regression analysis of 24 hour urinary excretion of protein and protein creatinine index on random specimens in all outpatients studied (groups 2-5).

\section{ALBUSTIX STUDIES}

The degree of proteinuria was misclassified by Albustix because no allowance could be made for urine concentration (table I gives details of specimens that were misclassified). No urine sample had a $\mathrm{pH}$ of more than 7 , thus eliminating one possible source of false positive results.

Sensitivity-A negative result should indicate the absence of proteinuria. In group 3 five of 27 patients gave negative Albustix results and eight $\left(30^{\circ}{ }_{0}\right)$ gave trace positive results with the random specimens. Using early morning specimens four of the 27 patients gave negative Albustix results and nine $\left(33^{\circ}{ }_{0}\right)$ gave trace results. Specimens from all patients in groups 4 and 5 showed a positive Albustix result of at least one plus $(+)$, with both random and early morning specimens.

Specificity-A positive result should predict the presence of proteinuria. Two of the 33 patients in group 2 (normal protein excretion) gave a positive Albustix result $(+)$ in the random specimen and eight gave a trace positive result. Using early morning specimens two of the 33 patients gave a positive $(+)$ result and 10 gave trace results.

Observer variation-The variations in the interpretation of Albustix were tested by preparing duplicate samples of protein solutions at different levels of protein concentration; staff tested all eight samples in one batch. There was a wide spread of results with all concentrations of protein tested (over $46 \mathrm{mg} / \mathrm{l}$ ) (table II). There were up to 
three graduation differences on the Albustix colour chart between observers at all concentrations tested-for example, from negative to one plus positive $(+)$ at a concentration of $218 \mathrm{mg} / \mathrm{l}$. There was a maximum of one graduation difference on the Albustix colour chart by the same observer with duplicate samples (table II).

TABLE I-Details of seven patients in whom Albustix gave misclassified results

\begin{tabular}{|c|c|c|c|c|c|}
\hline $\begin{array}{l}\text { Case } \\
\text { No }\end{array}$ & $\underset{\text { result }}{\text { Albustix }}$ & $\begin{array}{l}\text { Protein } \\
(\mathrm{mg} / \mathrm{l})\end{array}$ & $\begin{array}{c}\text { Creatinine } \\
(\mathrm{mmol} / \mathrm{l})\end{array}$ & $\underset{\text { (mg/24 hour) }}{\text { Protein }}$ & $\begin{array}{l}\text { Protein } \\
\text { creatinine } \\
\text { index on } \\
\text { random } \\
\text { specimens }\end{array}$ \\
\hline $\begin{array}{l}1 \\
2 \\
3 \\
4 \\
5 \\
6 \\
7\end{array}$ & $\begin{array}{l}\text { Positive (+) } \\
\text { Positive }(+) \\
\text { Negative } \\
\text { Negative } \\
\text { Negative } \\
\text { Negative } \\
\text { Negative }\end{array}$ & $\begin{array}{r}209 \\
241 \\
40 \\
71 \\
83 \\
96 \\
129\end{array}$ & $\begin{array}{r}21.2 \\
25.8 \\
1.3 \\
3.0 \\
2.5 \\
4.7 \\
3.5\end{array}$ & $\begin{array}{r}117 \\
56 \\
230 \\
395 \\
188 \\
182 \\
265\end{array}$ & $\begin{array}{r}99 \\
93 \\
308 \\
237 \\
332 \\
204 \\
369\end{array}$ \\
\hline
\end{tabular}

Conversion: SI to traditional units-Creatinine: $1 \mathrm{mmol} / 1 \approx 11 \cdot 3 \mathrm{mg} / 100 \mathrm{ml}$.

TABLE II-Variation in observers' assessment of Albustix on prepared duplicate protein samples

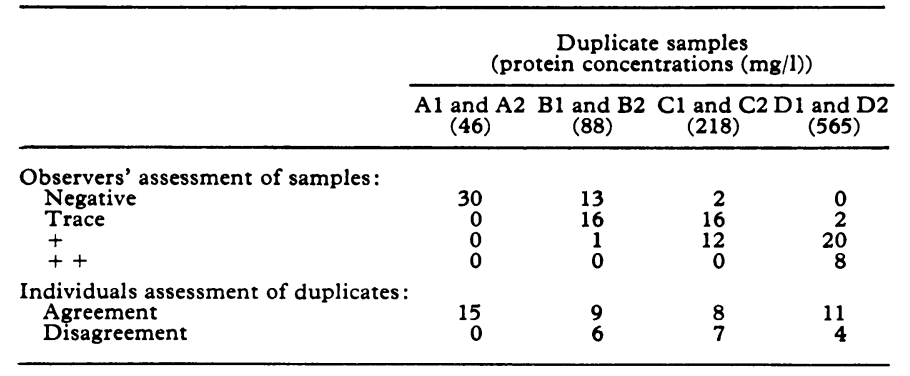

\section{Discussion}

The detection of minor degrees of proteinuria (below $500 \mathrm{mg} /$ 24 hours) is important in conditions such as diabetes mellitus, ${ }^{11}$ pregnancy, ${ }^{12}$ and systemic lupus erythematosus, ${ }^{13}$ but dipstick tests are unreliable for this purpose. ${ }^{4-6}$ False negative Albustix results would be expected in dilute urine where protein concentration is low although total excretion is abnormal. ${ }^{1}$ Our results confirm this as a major source of error which the protein creatinine index used on random specimens of urine corrects (table I). In patients whose daily excretion of protein was in the range $150-1000 \mathrm{mg}$ we found $19 \%$ false negative results and $30 \%$ trace positive results of uncertain relevance (makers' instructions) using Albustix in the random specimens, and 15\% negative and $33 \%$ trace positive in the early morning specimens. All were correctly assigned as being abnormal using the protein creatinine index on random samples.

Albustix was also non-specific, and in the random specimens trace positive results occurred in $25 \%$ and positive $(t)$ results in $6 \%$ of patients with normal daily protein excretion. Again these errors were in the urinary concentration and the specimens were classified as normal using the protein creatinine index (table I). Staff of all training grades could not interpret results from the Albustix colour chart reliably even when testing small numbers of samples. At the three concentrations of protein over $46 \mathrm{mg} / \mathrm{l}$ tested, half the observers were as likely to record results differing by one graduation on duplicate samples as to reproduce the reading correctly (table II). Observer variation is therefore an unavoidable source of error with dipstick tests.

Quantitative measurement of urinary excretion of protein over 24 hours is the definitive test for proteinuria. ${ }^{2}$ It is also used to establish the severity of a nephropathy, ${ }^{14}$ to differentiate glomerular and tubulointerstitial disease, ${ }^{15}$ to establish the presence of nephrotic syndrome, ${ }^{15}$ and to monitor the progress of nephropathy. ${ }^{1}$

Prolonged collections of urine are inconvenient and often inaccurate due to collection errors. ${ }^{3}$ The accuracy of a collection may be assessed by carefully questioning the patient or by measuring the 24 hour excretion of creatinine. ${ }^{18}$ The latter method may be unreliable as daily creatinine excretion fluctuates, and also reference ranges may be invalid for elderly, obese, oedematous, or wasted persons who excrete considerably less creatinine per kilogram body weight. ${ }^{8}$ Our relatively low rejection rate $(15 \%)$ can probably be ascribed to careful preselection of patients for cooperation and reliability. Because of the problems of timed urine collections these have been superseded by measuring a ratio of a substance to creatinine in random or early morning urine specimens ${ }^{17}$ and the results expressed as a ratio ( $\mathrm{mg}$ or $\mathrm{mmol} / \mathrm{g}$ or $\mathrm{mmol}$ creatinine). This method has been used for amylase, calcium, oestrogen, amino acids, catecholamines, and others and for urinary albumin by radioimmunoassay. Urinary protein creatinine ratios measuring protein by routine chemical methods have also been used but have not been widely adopted. ${ }^{18-20}$ It has probably been assumed that the protein content of a single urine sample could not accurately reflect total daily urinary excretion of protein because this fluctuates considerably during a 24 hour period, being reduced by recumbency or a high urine flow ${ }^{21}$ and increased by exercise. ${ }^{22}$

We found the protein creatinine index on random specimens to be very sensitive: all patients excreting more than $150 \mathrm{mg}$ protein a day had an index for random samples of more than 127. The index on early morning specimens was less sensitive and $15 \%$ of patients had results less than 108. These patients may have had a purely postural proteinuria and combined measurement of the index for early morning and random specimens may prove useful in the assessment of suspected orthostatic proteinuria. The indexes for random and early morning specimens were equally specific, and among normal subjects and patients with protein excretion below $150 \mathrm{mg} /$ day only one result in each case exceeded their respective upper reference limit.

To determine the usefulness of the protein creatinine index as a seniquantitative guide to daily excretion of protein we allocated our patients with proteinuria into three groups with different diagnostic implications. In at least $78 \%$ of cases the index for random specimens corresponded numerically to the 24 hour excretion of protein. The index for early morning specimens was less accurate at concentrations over $1000 \mathrm{mg}$ protein/day.

The mean index for early morning specimens was lower than that for random specimens at a given protein excretion, presumably because of the reduced protein concentration in overnight urine. The slope factor of the regression equation is higher for the early morning specimens than for random specimens, as is the intercept. The index for early morning specimens therefore provides a less useful semiquantitative measurement of proteinuria.

The index for random specimens is about numerically equal to the protein excretion in $\mathrm{mg}$ per 24 hours and this may arise because daily urine creatinine excretion is of the order of 10 $\mathrm{mmol} /$ day $(1.13 \mathrm{~g} /$ day $)$. We believe that the protein creatinine index provides a useful, convenient, and semiquantitative measurement of daily protein excretion and avoids many of the problems of 24 hour collections. In unreliable patients this index used on random specimens may be a better indicator of protein excretion than a 24 hour urine collection.

The relative accuracy of the index in predicting the daily urinary excretion of protein may depend on three factors. Firstly, correction is made for changes in urinary concentration and dilution by relating protein to creatinine. Secondly, in outpatients the sample of urine tested usually represents renal excretion during two to four hours of varied activity. Thirdly, most of the daily urinary excretion of protein of an outpatient takes place during activity not recumbency. ${ }^{18}$

We therefore advocate the use of the protein creatinine index on random specimens as a screening test for proteinuria, supplementing dipstick tests where the unreliability of these may be misleading. The index also provides a convenient 
estimation of daily excretion of protein in patients who may be unable to provide an accurately timed collection.

We would like to thank Dr A T Howarth for his constructive criticism of this manuscript and also Miss $S$ Wilson for preparing the manuscript.

\section{References}

1 Kassirer JP, Gennari FJ. Laboratory evaluation of renal function. In: Early LE, Cottschalk CW, eds. Diseases of the kidney. 3rd ed. Boston: Little Brown and Company, 1979:65-71.

2 De Wardener HE. Tests of glomerular functional integrity. In: De Wardener HE, ed. The kidney. 4th ed. London: Churchill Livingstone, 1973:42.

3 Kerr DNS. Normal values in renal medicine. Medicine $1982 ; 23: 1047-53$.

4 Thysell HA. A comparison between Albustix, Hemacombistix, Labstix, Hellers nitric acid test and a biuret method. Acta Med Scand 1969;185: 401-7.

${ }^{5}$ Gyure WL. Comparison of several methods for semiquantitative determination of urinary protein. Clin Chem 1977;23:876-9.

${ }^{6}$ Rennie IDB, Keen H. Evaluation of clinical methods in detecting proteinuria. Lancet 1967 ;ii:489-92.

${ }^{7}$ Rose BD. Diagnostic approach to the patient with renal disease. In: Rose $\mathrm{BD}$, ed. Pathophysiology of renal disease. New York: McGraw Hill Book Company, 1981:35.

${ }^{8}$ Best WR, Khul WJ Jr, Consolazio CF. Relation of creatinine coefficient to leanness-fatness in man. $f$ Lab Clin Med 1953;45:784

${ }^{9}$ Iwata I, Nishikaze O. New micro-turbidimetric method for the determination of protein in cerebro-spinal fluid and urine. Clin Chem 1979; $25: 1317$.
10 Stamper R, Robertshaw DM. Decreasing sample volume used in the "sequential multiple analyser computerised" (SMAC). Clin Chem $1980 ; 26: 778-80$

1 Viberti GG, Bilnis RW, Mackintosh D, Bendony JJ, Keen H. Long term correction of hyperglycaemia and progression of renal failure in insulin dependent diabetes. Br Med f 1983;286:598-602.

12 Cavanagh D, Knappel RA. Preeclampsia and eclampsia. In: Iffy L, Kassinetyky HA, eds. Principle and practice of obstetrics and perinatology. New York: John Wiley and Sons, 1981:1275-87.

13 Border WA. Diagnosis and management of lupus nephritis. American fournal of Nephrology 1981;1:53-67.

${ }^{14}$ Chen BT, Ooi BS, Tan KK, Lin CH. Comparative studies of asymptomatic proteinuria and haematuria. Arch Intern Med 1974;134:901-10.

15 Sweeney P. Asymptomatic proteinuria. Medicine (Baltimore) 1980;26: 1310-2.

16 Vestergaard P, Leverett R. Consistency of creatinine excretion. 7 Lab Clin Med 1958;51:211-5.

17 Tietz NW. Reference ranges and laboratory values of clinical importance In: Wyngaarden JB, Smith LH, eds. Cecils textbook of medicine. 16th ed. Philadelphia: WB Saunders, 1982:2320-54.

18 Toback FG, Hall PW, Lindheimer MD. Effect of posture on urinary protein patterns in non-pregnant, pregnant, and toxaemic women. Obstet Gynecol 1970;35:765-8.

19 Richmond JM, Sibbald WJ, Linton AM. Patterns of urinary protein excretion in patients with sepsis. Nephron 1982;31:219-23.

20 Eiser AR, Katy SM, Swartz C. Reversible nephrotic range proteinuria with renal artery stenosis. A clinical example of renin associated proteinuria. Nephron $1982 ; 30: 374-7$.

${ }^{21}$ King SE. Postural adjustments and protein excretion by the kidney in renal disease. Ann Intern Med 1957;46:360.

22 Campanacci L, Faccini L, Englavo E, et al. Exercise-induced proteinuria. Contrib Nephrol 1981 ;26:31-41.

(Accepted 17 fune 1983)

\title{
Role of hepatic arterial embolisation in the carcinoid syndrome
}

\author{
P N MATON， M CAMILLERI， G GRIFFIN， D J ALLISON， H J F HODGSON， V S CHADWICK
}

\begin{abstract}
Eighteen patients with severe symptoms of the carcinoid syndrome were assessed for hepatic embolisation. Four were too ill, and one had mild symptoms; thus 13 received a periembolisation regimen of cyproheptadine, fenclonine, aprotinin, methylprednisolone, tobramycin, flucloxacillin, and metronidazole. Embolisation was not performed in one patient with an occluded portal vein and was unsatisfactory in two others, in one because she was moribund and in the other because the hepatic artery had been ligated. Dramatic improvement in
\end{abstract}

Department of Medicine, Royal Postgraduate Medical School, London W12 0HS

P N MATON, MD, MRCP, research fellow

$M$ CAMILLERI, MD, registrar

G GRIFFIN, PHD, MRCP, registrar

H J F HODGSON, DM, FRCP, senior lecture

V S CHADWICK, MD, FRCP, senior lecture

Department of Radiology, Royal Postgraduate Medical School D J ALLISON, MD, FRCR, senior lecturer

Correspondence to: $\operatorname{Dr} P$ N Maton, Gastroenterology Unit, Royal Postgraduate Medical School, Du Cane Road, London W12. symptoms occurred in the nine patients in whom embolisation was successfully carried out, with abolition of flushing, severe abdominal pain, and wheeze and reduction in diarrhoea from 10.5 (SD 7.6 ) to $1.6(0.9)$ stools/day. Urinary excretion of 5-hydroxyindole acetic acid fell from 1048 (716) to 289 (184) $\mu \mathrm{mol} / 24 \mathrm{~h}(200$ (137) to 55 (35) $\mathrm{mg} / 24 \mathrm{~h}$ ). Complications included one death from septicaemia, a hepatic abscess requiring surgical drainage, abdominal pain in three patients, pleural effusion in two, and transient encephalopathy in one. Relief of symptoms lasted for one to 24 months, and second embolisation in two patients produced further remissions of four to six months. Five patients died, one to $\mathbf{4 0}$ months after embolisation, in four cases because of metastases or heart failure.

Hepatic embolisation is the treatment of choice for symptoms of the carcinoid syndrome resistant to medical treatment.

\section{Introduction}

The carcinoid syndrome is characterised by flushing, diarrhoea, heart disease, and wheezing and in most cases is associated with extensive metastases from a malignant gastrointestinal tumour. ${ }^{1}$ In general these tumours are of low grade malignancy, and survival of up to 20 years despite symptoms has been reported." Nevertheless, the range of the disease is wide, and other series 